Contents list avaliable at Directory of Open Access Journals (DOAJ)
Aulad : Journal On Early Childhood
Vol 3 No 2 2020, Pages 115-114
ISSN : 2655-4798 (Printed); 2655-433X (Online)
Journal Homepage: https://aulad.org/index.php/aulad

\title{
The Gross Motor Skill Differences Between Preschool Boys and Girl
}

\author{
Nurul Arifiyanti ${ }^{1}$ \\ Pendidikan Islam Anak Usia Dini, Sekolah Tinggi Agama Islam Nahdlatul Ulama \\ DOI: 10.31004/aulad.v3i3.78
}

\begin{tabular}{|c|c|}
\hline Article Info & Abstract \\
\hline $\begin{array}{l}\text { Keywords: } \\
\text { Gross Motor } \\
\text { Preschool } \\
\text { Development } \\
\text { Gender } \\
\text { Skill }\end{array}$ & $\begin{array}{l}\text { Every stage in human development has different phase. Not only in every stage but } \\
\text { also in gender, motor skill has their own characteristics. Moreover, there is a } \\
\text { question of the validity and reliability of some tests used by the researcher. The } \\
\text { study was conducted in Purworejo, Jawa Tengah, Indonesia. A total of } 82 \text { children } \\
\text { enrolled in this study, including } 12 \text { children aged between } 3-4 \text { years, } 36 \text { children } \\
\text { aged between } 4 \text { and } 5 \text { years, and } 34 \text { children aged between } 5 \text { and } 6 \text { years. The test } \\
\text { of gross motor development-second (TGMD-2) edition was used to evaluate gross } \\
\text { motor skill. Independent T-test was used to analyzed the final result. The findings } \\
\text { of this study demonstrated that the boys have higher gross motor skills } \\
\text { performance than the girls. The school can use this fact to plan curriculum that not } \\
\text { based in gender. School must be a campaign system for gender equality. }\end{array}$ \\
\hline
\end{tabular}

Kata kunci:

Motorik Kasar

Prasekolah

Perkembangan

Gender

Keterampilan

\begin{abstract}
Abstrak
Setiap langkah perkembangan manusia memiliki tahapan yang berbeda. Tidak hanya pada aspek usia namun juga gender, keterampilan motorik memiliki karakteristik yang berbeda. Lebih lanjut, beberapa instrumen tes yang digunakan untuk mengukur kemampuan anak belum tentu valid dna reliabel. Penelitian ini dilakukan di Purworejo, Jawa Tengah Indonesia. Sebanyak 82 anak menjadi partisipan, 12 anak usia 3-2 tahun, 36 anak usia 4-5 tahun, dan 34 anak usia 5-6 tahun. TGMD- 2 digunakan sebagai instrumen pengukuran. Data kemudian dianalisis menggunakan uji $\mathrm{T}$ independent. Hasilnya, anak laki-laki memiliki kemampuan motorik kasar lebih tinggi daripada perempuan. Sekolah dapat mempertimbangkan hasil ini dalam peyusunan kurikulum yang meghindari adanya bias gender. Mereka harus menjadi tempat dimana kesetaraan gender diutamakan.
\end{abstract}

\section{INTRODUCTION}

Many motors skill research was conducted even they're not too specified. As we know, every stage in human development has different phase. Not only in every stage but also in gender, motor skill has their own characteristics. Moreover, there is a question of the validity and reliability of some tests used by the researcher. We have to ensure that our instruments have a good validity and reliability. Therefore, the problem of assessing the motor skill still evident in preschool age (Pelemis, V., Pavlovic, S., \& Anicic, 2018).

Preschool children make great advanced in gross motor skills, such as jumping, running, walking, climbing, which involve the large muscle (Papalia, D.E., Olds, S.W., Feldman, 2007). Development of the motor area in their brain make them can coordinate the sensory and what they want to do. Add with their deep curiosity with this world and the full energy, preschooler always move from one side to others. They running around the school yard, touching

\footnotetext{
${ }^{1}$ Pendidikan Islam Anak Usia Dini, Sekolah Tinggi Agama Islam Nahdhatul Ulam, Purworejo, Jawa Tengah Indonesia Email: nurularifiy@gmail.com
} 
all the item in the class, playing water, and building something in the sand even the risk of accident can happen at any time.

The general gender discourse has currently revealed gender gaps as early as at preschool age (Lewicki, Franze, \& Gottschling-lang, 2018). Boys have higher risk to be falling down when playing than girls. The more energy makes them more active all day long in the school. Many outdoor games make boys feel challenged. Climbing, running, and jumping are some of the activity that they like. They are progressively falling behind girls in international student assessments, such as PISA (OECD, 2009) and IGLU (Mullis, Martin, Kennedy, \& Foy, 2007). It can't be concluded yet that the gross motor in boys are better than the girls, especially in. Therefore, this paper tries to analyze gross motor developmental differences between boys and girls in preschool years.

Motoric is line with the movement activity either using an object or not. The movement using big muscle has known as gross motor skill (Santrock, 2007). Another ideas state that gross motor development is the skills involved in control of the large muscles of the legs, arms, back, and shoulders (Essa, 2014). This skill is influenced by the maturation of nervous system and also life experience. Therefore, early childhood needs more space, opportunities, and trust from the environment to get it. This help children get the maximum development of motoric and will influenced other areas.

Child's gross motor behavior changes dramatically during 8 yeas of life. This is the most visible aspect of early years development because everyone can see it once they meet. Since baby, the parent waits for them to entrance the next stage. From lying down, crawling, and then walking. It will be continuing until the children can run, jump, climb, and et all. Unconsciously, the children have a great achievement in their motor development.

Fundamental motor skills (FMS) include both locomotor (e.g. run, jump, leap, and hop) and object control skills (e.g. throw, catch, kick, and strike) (Gallahue, D., J. Ozmun, 2012). Locomotor skill causes the children get a movement from one side to others. In contrast with non-locomotor skill which cause the child stay same with the first position. The examples are going nowhere, moving hands up, looking right and left, and hopping on the spot. Object control also known as manipulative skill which use a thing when doing physical activity. It can use balls, rope, board, sticks, hula-hoop, and etc.

Research had shown that FMS is influenced by age, gender, physical activity, and preschool-based programs(Livonen \& Sääkslahti, 2014). The older aged children demonstrated more competency in motor skills than the younger. The older has mature muscle and good coordination. Boys performed better than girls in manipulative skills. Environment plays an important role for this difference. Not only in the family, but also in the school physical activity is needed to develop children's motor skill. Planned program is needed by the school with supported by the good infrastructure.

Parents of males more frequently made statements to promote gross motor skills while parents of females more frequently made statements to promote fine motor skills (Dinkel \& Snyder, 2020). Parents' statement relates to give motivation for children in their activity. It also shows in our culture. According to Indonesian's family especially in Java, play based gender is an important aspect. Girls must have a warm and soft behavior, and boys must be a gentleman, don't cry, and strong. This view has impact on what the children playing with and also their motor development

There was a significant positive association between gross motor skills and toddler's cognitive development (Veldman, Santos, Jones, Sousa-sá, \& Okely, 2019). This also had been proved that both locomotive and object manipulation were also significantly positively associated with cognitive development. Motor skills influence the prefrontal cortex which located precise behind of the forehead. The function of the prefrontal cortex is for thinking, planning, deciding something, controlling emotion and body, and understanding ourself. This area is co-activated during motor activity which need full of good control and coordination.

Child's academic performance can be improved by increasing the motor activity skill. Object manipulation tasks had significant effects on 2nd grade reading and math achievement (Dinehart \& Manfra, 2013). Children use their sensory and part of their bodies to learn. They must get the movement from one side to other side to get new information. This the best way for children to explore their environment. They like touch everything and never think it will get them injury or not. The best way of children's learning is learning in their own ways so it will give meaningful learning. Therefore, in our new education system, the student must be the center of learning not teacher. The activity must be depended on the children's interest. This will increase the learning motivation so that children's academic performance can be improved well.

The problem of the research was to analyze whether there were statistically significant differences in gross motor abilities between boys and girl of the preschool age 2 and 6 from Purworejo. We tried to know and determine quantitative characteristics of gross motor abilities. .

\section{METHODS}

The study was conducted in Purworejo, Jawa Tengah, Indonesia. Five preschools were randomly selected. Principals and teacher agreed to participated in our study. They made this study included in the learning process. $A$ total of 82 children enrolled in this study, including 12 children aged between 3-4 years, 36 children aged between 4 and 5 years, and 34 children aged between 5 and 6 years. 
The test of gross motor development-second (TGMD-2) edition was used to evaluate gross motor skill (Ulrich, n.d.). TGMD-2 was designed to assess the gross motor functioning in children 3 through 10 years of age and has empirically determined reliability and validity. This measures 12 gross motor skills that may be taught to children in preschool. It has two subtest, locomotor and object control. The locomotor subtest measures gross motor skills that require big muscle when coordinated movements of the body included run, gallops, hop, leap, horizontal jump, and slide. Next, the object control subtest measures children's skill when using an object to show their big muscle skills included striking a stationary ball, stationary dribble, catch, kick, overhand throw, and underhand roll.

According to TGMD-2 manual, each skill has performance criteria to describe performance quality. If the children performed the criterion correctly, then they get one as a score. If the children performed incorrectly, they get the zero score. Each skill was done by the children twice, and the observer score the skills with observation sheet. After assessment, the raw scores of each gross motor skill were obtained by averaging the scores of all criterion. It ranges from 3 to 5 points. The total raw scores for locomotor and object control skills were obtained by summing in range from 0 to 12 points.

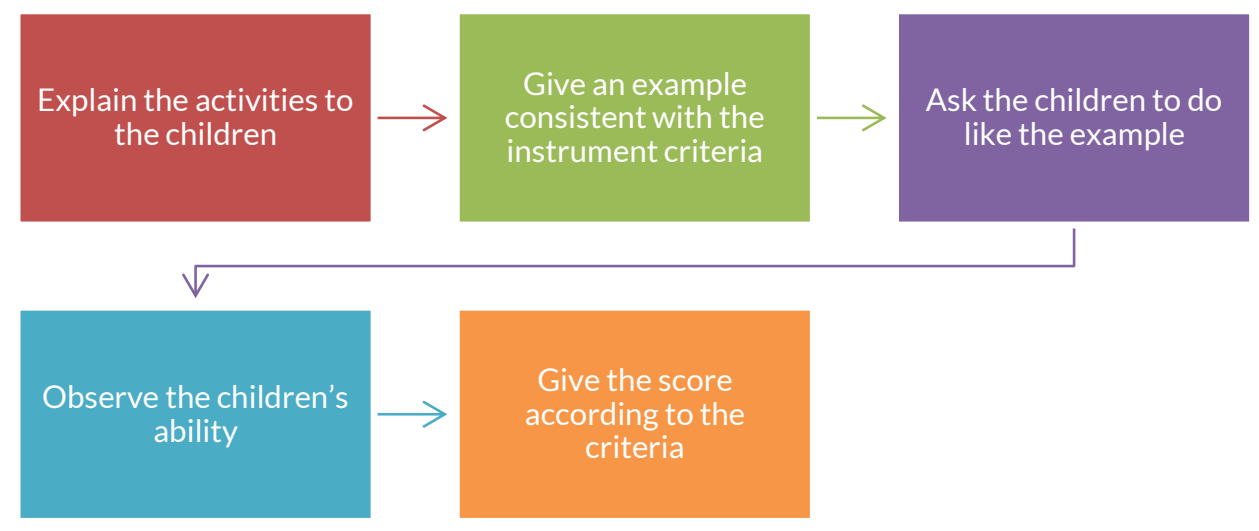

Figure 1. Data Collection Scheme

The data were collected from August to December 2019. All the measurements were conducted in the morning before the class began. The teacher started by verbal description and showing participants how to perform each gross motor skill. They only give once demonstration to the children. To get the consistent data, the teacher asked the children to perform each skill twice. Independent T-test was used to analyzed the final result. Descriptive analysis was calculated for all the variables. All analysis was performed using SPSS (version 16.00) with results were considered significant at a level of $<0.05$

\section{RESULT AND DISCUSSION}

From the table 1, it can be stated that the boys were higher than the girls both in locomotor subtest and object control test. Even the mean shows that boys have higher score in gross motor skills, there were some girls who got the highest score. Moreover, the minimum score of object control for the girls are higher than boys. Not all students followed both subtests. Someone was sick, someone asked for permission, and someone feel shy to do what teacher asked. This make they got very low score.

Tabel 1. Descriptive Statistics of Gross Motor Subtest

\begin{tabular}{lcllll}
\hline No & Subtest & Groups & Mean & Max & Min \\
\hline 1 & Locomotor & Boys & 15.8 & 24 & 4 \\
& & Girls & 12.6 & 24 & 2 \\
2 & \multirow{2}{*}{ Object control } & Boys & 15.9 & 24 & 3 \\
& & Girls & 13.1 & 23 & 4 \\
\hline
\end{tabular}

Boys were higher in all subtest aspect of locomotor skill (Figure 1.). There is only one skill in locomotor subtest that is not far away. The gallops skill between boys and girl just clash around 0.063 . It is the smallest different compare with run 0.49 , hop 0.85 , leap 0.80 , horizontal jump 0.29 , and slide 0.69 .

The result above slightly different with object control skill (Figure 2.). The boys are still higher than the girls in five aspects. There is one skill that the girls are higher than boys. It is striking a stationary ball skill. Using ball and batting tee, the girls looked to be more skilled. The difference in this skill reaches 0.65 . The others skill that make quite distance are kick 1.15, underhand roll 0.74 , and overhand throw 1.06. Meanwhile, catch 0.37 and stationary dribble 0.09 are not much different. 


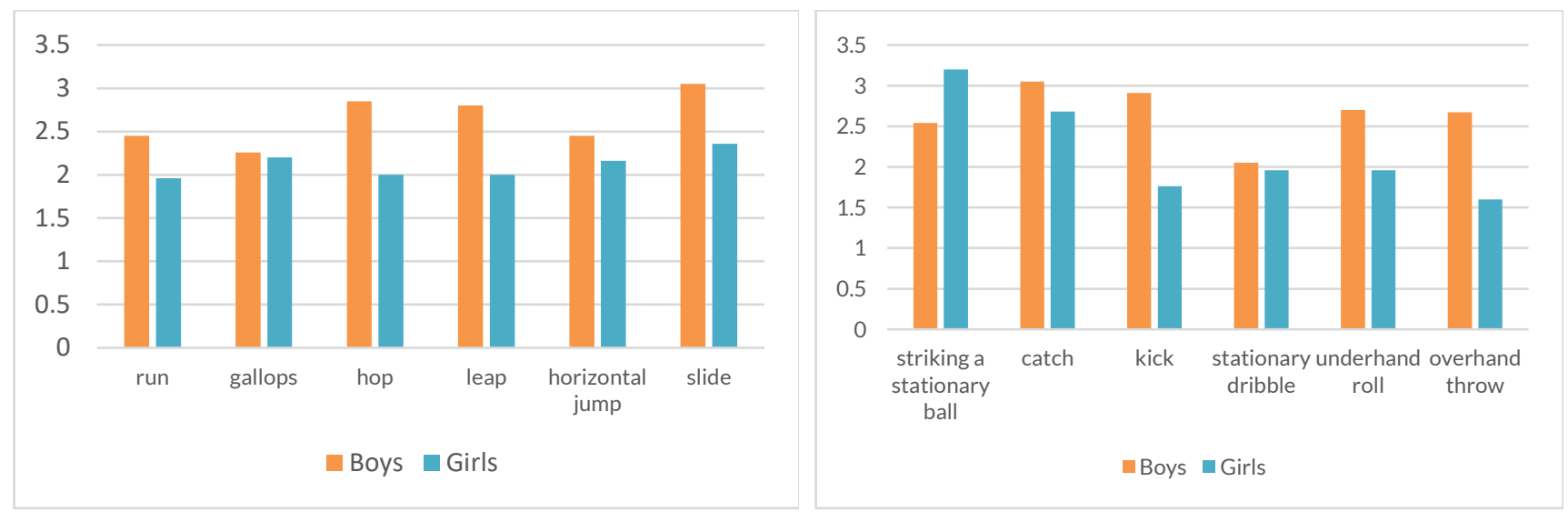

Figure 1. Mean of Locomotor Subtest

Figure 2. Mean of Object Control Subtest

Table 2. show that score of sig. Levene's Test for Equality of Variances is 0.326 . It means that the data have the homogeneity (score $>0.05$ ). Then based on the score of Sig. (2-tailed) 0.08 , it can be concluded that there is a significant difference in gross motor skill between boys and girls (score $<0.05$ ). The difference between the mean of the two groups is 5.98 .

Table 2. Independent Sample Test

\begin{tabular}{lccc}
\hline \multicolumn{1}{c}{ Variable } & Sig. & Sig. (2-tailed) & Mean Difference \\
\hline $\begin{array}{l}\text { Gender } \\
\text { (Boys and Girls) }\end{array}$ & 0.326 & 0.008 & 5.98 \\
\hline
\end{tabular}

The findings of this study demonstrated that the boys have higher gross motor skills performance than the girls. Moreover, the object control subtests both the boys and the girls have higher score than the locomotor subtests. There is one of the locomotor subtests that have little bit different. Surprisingly, the girls showed higher in striking stationary ball than the boys. Gender have an effect on the gross motor ability of young children (Colombodougovito, 2017). Our study consistent with his result that provide boys are better in perform gross motor skill than girls. Young boys are encouraged to perform more proficient in the fundamental motor task. Young girls are encouraged to participate using balance and carefulness.

One longitudinal and six cross-sectional studies across four different countries using five different instruments to assess fundamental motor skill indicated that boys performed better than girls (Livonen \& Sääkslahti, 2014). Environmental factors have high influenced in motor skills difference than biological factors. Boys may perform better in catching, running, and throwing because it is reasonable to consider that they play more active with all the things which they find. They try to hop between two of rocks, biking through the uphill road and jump with bike over the obstacle, running from one side to other side. Some of this activity stimulate boys have better coordination, good adrenaline so they do not fear to be falling down, and always to do something new with his friends. "What will be happened if I try to jump in to the lake or river or a poll?" This is what the society or environment give to boys. They encourage them to play outside and find their interest without any anxious from parent.

Furthermore, parents of male more frequently make statements to promote gross motor skills while parents of female more frequently make statement to promote fine motor skills (Dinkel \& Snyder, 2020). It also happened in Indonesian society. They make distance for boys and girl when playing or doing a hobby. Soccer, climbing, and jumping are for boys while girls have to be soft like playing dolls, cooking, and dancing. Environment give the support for boys to be a strong man. Therefore, parent's statement is very important to make the children get down or freely explore around.

Our result also consistent with previous research which identified that girls have better performance in all manual dexterity tasks. The score of girls when did the striking stationary ball is higher than boys. It can be caused by visual perception, socio-cultural and environmental factors including that girls spend more time than boys involved in tasks which require more dexterous movements (Thomas \& French, 1985; Valtr, Psotta, \& Abdollahipour, 2016). Girls have good coordination and balance because they always be careful and environment suggest that. Parent and family a like that their daughter do the save playing. The viewing that the girls are subject that must be protect more than boys effects the chosen of their activity.

Moreover, these results provide contrast to the previous research on gender. Both boys and girls have similar locomotor skills because both genders had equal opportunities or barriers in locomotor skills (Goodway, Robinson, \& Crowe, 2013). It can be happened at disadvantage children who come from low income parent. The busy 
parent and low educational background caused them do not give more attention to what children do. So, the children can explore the environment freely and without any worries.

Furthermore, previous research found no differences between boys and girls in locomotor skill performance in either childhood or adolescence (Barnett, Beurden, Morgan, Brooks, \& Beard, 2010). Boys and girls have similar performance curves in the jump skill until around age 11 years. The experience in early years will influence the adolescence's skill. Developing childhood skill in catching, kicking, and throwing may be equally important for adolescence boys and girls. The subject in this study involve subjects from child to adulthood with large sample and become a longitudinal study. The research may be biased due to several factors beyond its control. They cannot control the participants because of the long period make them moved between region and schools. Therefore, the results of these studies need another research to confirm.

One of the strengths of this study is the use of validated and reliable instrument which analyze 12 skill in gross motor development. On the other hand, the data collection was done by the teacher so the children get the examples without a sense of awkwardness. If the children ask to do the skill by other people that they do not know, they may be shy and do not want to do. Therefore, our data and score show the truth child's ability. This provide a better guideline in designing and planning better program that focus on gross motor skill as a strategy to promote other area of children development.

This study was limited to a rural area of Purworejo, Jawa Tengah and may not be applicable to other areas of the state. Therefore, future studies should consider other areas including urban locations and suburban locations. A further limitation is that the study design was cross-sectional by making the observations twice. On the other hand, the participants of this study are not much. It is suggested that a longitudinal design with large sample will reveal more findings in determining gender differences in gross motor skill.

\section{Conclusion}

This research confirms the presence of statistically significant differences according to the gender differences in the area of gross motor skill. With the two subtests are present in the following variables: the locomotor subtest (run, gallops, hop, leap, horizontal jump, and slide) and the object control subtest (striking a stationary ball, stationary dribble, catch, kick, overhand throw, and underhand roll). Generally, it can conclude that the boys perform better gross motor skill than the girls. The school can use this fact to plan curriculum that not based in gender. The boys and girl need a balancing change to try everything they want. School must be a campaign system for gender equality. Therefore, there is not a difference again in their gross ability.

\section{REFERENCES}

Barnett, L. M., Beurden, E. Van, Morgan, P. J., Brooks, L. O., \& Beard, J. R. (2010). Childhood to Adolescence Gender Differences in Motor Skill Proficiency From Childhood to Adolescence : A Longitudinal Study. Research Quarterly for Exercise and Sport, 81(2), 162-170. https://doi.org/10.1080/02701367.2010.10599663

Colombo-dougovito, A. M. (2017). Exploring the Effect of Gender and Disability on Gross Motor Performance in Kindergarten Children. The Physical Educator, 74, 183-197.

Dinehart, L., \& Manfra, L. (2013). Early Education and Development Associations Between Low-Income Children's Fine Motor Skills in Preschool and Academic Performance in Second Grade Associations Between LowIncome Children' s Fine Motor Skills in Preschool and Academic Performance in Se. Early Education and Development, 24(2), 138-161. https://doi.org/10.1080/10409289.2011.636729

Dinkel, D., \& Snyder, K. (2020). Infant Behavior and Development Exploring gender differences in infant motor development related to parent's promotion of play. Infant Behavior and Development, 59(March), 101440. https://doi.org/10.1016/j.infbeh.2020.101440

Essa, E. L. (2014). Introduction Early Childhood Education. California: Wadsworth P.Co.

Gallahue, D., J. Ozmun, J. D. G. (2012). Understanding Motor Development: Infants, Children, Adolescents and Adults. New York: McGraw-Hill.

Goodway, J. D., Robinson, L. E., \& Crowe, H. (2013). Research Quarterly for Exercise and Sport. Research Quarterly for Exercise and Sport, 1(81), 17-24.

Lewicki, K., Franze, M., \& Gottschling-lang, A. (2018). Developmental differences between preschool boys and girls in Northeastern Germany in Northeastern Germany. European Early Childhood Education Research Journal, 26(3), 316-333. https://doi.org/10.1080/1350293X.2018.1462997

Livonen, S., \& Sääkslahti, A. K. (2014). Preschool children 's fundamental motor skills : a review of significant determinants. Early Child Development and Care, 184(7), 11107-11126. https://doi.org/10.1080/03004430.2013.837897

Mullis, I. V. S., Martin, M. O., Kennedy, A. M., \& Foy, P. (2007). PIRLS 2006 International Report: IEA's Progress in International Reading Literacy Study in Primary Schools in 40 Countries. United States: TIMSS \& PIRLS International Study Center, Lynch School of Education, Boston College.

OECD. (2009). Equally prepared for life? How 15 year Old Boys and girl perform in School.

Papalia, D.E., Olds, S.W., Feldman, R. . (2007). Human Development, Tenth Edition. 
Pelemis, V., Pavlovic, S., \& Anicic, Z. (2018). Differences In Motor Skils Between Preschool Boys And Girls. Educatia Plus, XIX(1), 176-184.

Santrock, J. W. (2007). Perkembangan Anak. (M. Rachmawati \& A. Kuswanti, Eds.) (11th ed.). Jakarta: Erlangga.

Thomas, J. R., \& French, K. E. (1985). Gender Differences Across Age in Motor Performance : A Meta-Analysis. Psychological Bulletin, 98(2), 260-282.

Ulrich, D. A. (n.d.). Test Gross Motor Development 2 (TGMD-2).

Valtr, L., Psotta, R., \& Abdollahipour, R. (2016). Gender differences in performance of the Movement Assessment Battery for Children - 2 nd edition test in adolescents. Acta Gymnica, 46(4), 155-161. https://doi.org/10.5507/ag.2016.017

Veldman, S. L. C., Santos, R., Jones, R. A., Sousa-sá, E., \& Okely, A. D. (2019). Early Human Development Associations between gross motor skills and cognitive development in toddlers. Early Human Development, 132(March), 39-44. https://doi.org/10.1016/j.earlhumdev.2019.04.005 